\title{
Dornase alpha use in patients with cystic fibrosis
}

\author{
O uso de alfadornase em pacientes com fibrose cística \\ El uso de alfadornasa en pacientes con fibrosis quística
}

Paulo José C. Marostica'

Cystic Fibrosis (FC) is an autosomal recessive disorder with an estimated incidence of one in 7,500 live births in Brazil, varying in different states ${ }^{(1)}$. The gene in question encodes a protein called cystic fibrosis transmembrane conductance regulator (CFTR), involved in the transepithelial transport of ions and water. It affects, thus, the epithelial organs whose secretions are thick, with consequent obstruction and development of classical clinical changes.

In the bronchial tubes, thickened secretions predispose to the onset of infection, which leads to a vicious cycle of increased clogging and tendency of recurrent infections. About $10 \%$ of sputum in these patients is made up of DNA, primarily from leukocytes that migrate into the bronchial lumen to fight infection ${ }^{(2)}$.

Within this perspective, the use of effective mucolytics was always sought for a better management of CF, aiming at improving the quality of life and reducing the associated morbidity.

From about two decades ago, dornase alfa has been recommended for use in patients with CF. Its action, cleaving DNA, dilutes secretions, being effective in reducing the decline in lung function and decreasing the number of pulmonary exacerbations, according to a randomized clinical trial published in $1994^{(3)}$. Later, other studies showed that the drug was effective in reducing pulmonary exacerbations and improving other functional outcomes, even in patients with incipient pulmonary disease, still with normal functional parameters $^{(4-9)}$. The proven effectiveness of dornase alfa in such conditions led to its inclusion in consensus guidelines on the management of $\mathrm{CF}$ lung disease for children over 6 years of age $\mathrm{e}^{(10,11)}$.

In this issue of Revista Paulista de Pediatria, Rozov et al present an elegant study, in which they aggregate evidence for the use of dornase alfa in children and adolescents with $\mathrm{CF}^{(12)}$. The Brazilian multicenter study evaluated patients over 5 years of age who had not received the drug. CF is a genetic disorder whose development is influenced by environmental factors. Therefore, the merit of this study lies in the fact that it demonstrates the benefits of dornase alfa in Brazilian patients, regarding the reduction of visits to the emergency room, an outcome associated with quality of life. Previously, the authors had already published results of quality of life for these patients, showing improvements in many areas after the introduction of this medication ${ }^{(13)}$.

A limitation of the study that should be mentioned is its uncontrolled design. There are inherent limitations to studies with a design of "before and after". Patients monitored in surveys tend to be more compliant and subject to the placebo effect. However, ethical constraints absolve the authors as to the choice of the design, since there was already evidence of the benefit of the drug in children older than 6 years, a fact that advised against a control group with placebo.
Instituição: Universidade Federal do Rio Grande do Sul (UFRGS), Porto Alegre, RS, Brasil

IUFRGS, Porto Alegre, RS, Brasil
Endereço para correspondência:
Paulo José C. Marostica
Rua Borges do Canto, 241
CEP 90630-020 - Porto Alegre/RS
E-mail: pjcm@brturbo.com.br
Conflito de interesse: nada a declarar

Recebido em: 29/7/2013 


\section{References}

1. Raskin S, Pereira-Ferrari L, Reis FC, Abreu F, Marostica P, Rozov T et al. Incidence of cystic fibrosis in five different states of Brazil as determined by screening of p.F508del, mutation at the CFTR gene in newborns and patients. J Cyst Fibros 2008;7:15-22.

2. Chernick WS, Barbero GJ. Composition of tracheobronchial secretions in cystic fibrosis of the pancreas and bronchiectasis. Pediatrics 1959;24:739-45.

3. Fuchs HJ, Borowitz DS, Christiansen DH, Morris EM, Nash M, Ramsey BW et al. Effect of aerosolized recombinant human DNase on exacerbations of respiratory symptoms and on pulmonary function in patients with cystic fibrosis. The Pulmozyme Study Group. N Engl J Med 1994;331:637-42.

4. Amin R, Subbarao P, Lou W, Jabar A, Balkovec S, Jensen R et al. The effect of dornase alfa on ventilation inhomogeneity in patients with cystic fibrosis. Eur Respir J 2011;37:806-12.

5. Robinson TE, Goris ML, Zhu HJ, Chen X, Bhise P, Sheikh F et al. Dornase alfa reduces air trapping in children with mild cystic fibrosis lung disease: a quantitative analysis. Chest 2005;128:2327-35.

6. Ratjen F, Paul K, van Koningsbruggen S, Breitenstein S, Rietschel E, Nikolaizik W. DNA concentrations in BAL fluid of cystic fibrosis patients with early lung disease: influence of treatment with dornase alpha. Pediatr Pulmonol 2005;39:1-4.

7. Quan JM, Tiddens HA, Sy JP, McKenzie SG, Montgomery MD, Robinson PJ et al. A two-year randomized, placebo-controlled trial of dornase alfa in young patients with cystic fibrosis with mild lung function abnormalities. J Pediatr 2001;139:813-20.

8. McCoy K, Hamilton S, Johnson C. Effects of 12-week administration of dornase alfa in patients with advanced cystic fibrosis lung disease. Pulmozyme Study Group. Chest 1996;110:889-95.

9. Jones AP, Wallis C. Dornase alfa for cystic fibrosis. Cochrane Database Syst Rev 2010;(3):CD001127.

10. Heijerman H, Westerman E, Conway S, Touw D, Döring G; Consensus working group. Inhaled medication and inhalation devices for lung disease in patients with cystic fibrosis: a European consensus. J Cyst Fibros 2009;8:295-315.

11. Mogayzel PJ Jr, Naureckas ET, Robinson KA, Mueller G, Hadjiliadis D, Hoag JB et al. Cystic fibrosis pulmonary guidelines. Chronic medications for maintenance of lung health. Am J Respir Crit Care Med 2013;187:680-9.

12. Rozov T, Abreu e Silva FA, Santana MA, Adde FV, Mendes RH; Brazilian Cystic Fibrosis Multicenter Study Group. A first-year dornase alpha treatment impact on clinical parameters of patients with cystic fibrosis: results from Brazilian cystic fibrosis multicenter study. Rev Paul Pediatr 2013;31:420-30.

13. Rozov T, de Oliveira VZ, Santana MA, Adde FV, Mendes RH, Paschoal IA et al. Dornase alpha improves the health-related quality of life among Brazilian patients with cystic fibrosis - a one-year prospective study. Pediatr Pulmonol 2010;45:874-82 